\title{
Study of Strategic Adjustment of Ideological and Political Work in Colleges and Universities under the Background of the Omni-Media Era
}

\author{
Xiao Jun \\ Wuhan Technology and Business University; Wuhan 430000 China
}

Keywords: Omni-media era; Ideological and political work in colleges and universities, strategy adjustment

\begin{abstract}
With the continuous development of information technology, mobile phone, computer and Internet technology are becoming more and more popular. The dissemination of information has been developed rapidly. Our era has also entered the age of Omni-Media; people also put forward new requirements for ideological and political work in universities. Therefore, under the background of the Omni-Media era, it is necessary for us to carry out ideological and political work with new understanding and media means. This paper has put forward corresponding strategies on the adjustment of ideological and political work in colleges and universities by analyzing the characteristics of the Omni-Media era and the necessity of ideological and political work.
\end{abstract}

\section{The Concept of Omni-Media Age}

The concept of Omni-Media was first proposed by Americans, which literally means using Omni-Media to disseminate information. Thanks to the development of Internet technology and continuous progress of science and technology, mobile phones and computers are becoming more and more popular in daily life, and social software is booming, people can have access to a lot of information on the Internet. We use pictures, video, audio and so on to achieve the function of information transmission. The concept of omni media was born in this context. Although the concept of Omni-Media is not accepted by the academic circle, it cannot be denied that it has deeply influenced people's life and exerted a significant influence on the change of historical process[1].

In the past era of traditional media, people received information more through newspapers, TV and other means. The mode of receiving information was relatively simple, and was easily influenced by the news media. The development of media means enables people to have a comprehensive understanding of the event from various perspectives and make their own judgment.

Omni-Media not only includes the diversification of communication tools, such as newspaper, magazine, radio, radio, Internet and other communication tools. It also covers audio-visual, tactile and other forms. It can select the most appropriate communication tools and channels for the public to spread information, so as to achieve the best communication effect.

Nowadays, more and more people begin to use new methods and technologies to complete information collection. Traditional media has gradually retreated from the stage of history or appeared in the age of omni media in new forms. People's access to information has been greatly enriched, and media workers can better serve people. This marks that we have fully entered the new media era.

\section{The Characteristics of the Omni-Media Era and Its Influence on the Ideological and Political Work in Colleges and Universities}

The current age of omni media means it's an age of information explosion, where people are more susceptible to different voices. This phenomenon is reflected in the ideological and political work of colleges and universities, that is, the ideological and political class teachers indoctrinate and influence the students' thoughts, but the students are extremely vulnerable to the influence of bad thoughts on the Internet, resulting in a great discount in the teaching effect. This is a great challenge to our university's ideological and political work in the Omni-Media era. In addition, as the youth of the new era, the 
students in universities are highly receptive to new things and can skillfully use new media to obtain the information they want. Therefore, the Omni-Media era has great influence on students.

Our teachers are powerless in this situation; they feel that their teaching cannot achieve the desired effect. This is mainly because the teacher does not combine new media means with teaching work, but still USES the single book teaching method, which leads to the students' lack of enthusiasm for learning and their lack of serious study of ideological and political content. Therefore, how to carry out the ideological and political work in colleges and universities well in the omni media era is a problem that cannot be ignored in front of us.

For the advent of the omni media era, other industries have also been impacted to some extent. In media journalism industry, all the arrival of the era of media make them more convenient to collect information, improve work efficiency, also make the news more comprehensive, but on the other hand, the diversification of media, also caused the information too multifarious, authenticity is difficult to determine, can cause great impact to the authenticity of news reports. If the fake news is widely spread, it will have a negative impact on the audience's values and outlook on life. As a large part of the audience, college students will bear the brunt of the impact. Therefore, regulating the development of news media in the new era has great influence on the development of ideological and political work in universities.

Among Omni-Media era, the spread of a variety of means has the characteristics of expansion and integration type, expanding refers to all the media means to constantly enrich and develop, efforts on Omni-Media transmission methods, which use different forms to audience provides vivid details of the news reports, the transmission on the way to win, and integration of Omni-Media technology refers to the development of new media means at the same time, the combination of traditional media and new media means, as an organic whole, use a variety of means to accomplish for the comprehensive coverage of an event.

Thus, in Omni-Media, under the age of information dissemination has spread rapidly, low cost, wide range of characteristics, these characteristics determine the good information or the spread of false information has the characteristics of rapid widely, and false information in the spread of easier to attract people's attention, caused the extensive discussions of public opinion, this will cause the spread of false information is more rampant. Therefore, it brings a greater challenge to the ideological and political work in universities. But we should also recognize that the arrival of the Omni-Media era has not only brought challenges to ideological and political work in universities, but also brought new opportunities. How to use the latest technological means to promote the development of ideological and political work in colleges and universities, so that we can work on the following key content.

\section{Current Situation of Ideological and Political Work in Colleges and Universities}

Our university thought political lesson's education has developed for many years. The ideological and political course in colleges and universities is an important course for the talents cultivated by the state to become the constructors of the socialist cause. The vast majority of college students not only need to have profound knowledge reserve and professional skills, but also need to have a high level of ideological and political culture. Only in this way can they truly serve the construction of the motherland and socialism. Therefore, the effect of the political course in colleges and universities is closely related to the ideological level of college students, and further affects the construction of the socialistcause.

However, due to the limitations and influences of The Times, the methods and methods of ideological and political education are relatively simple and old-fashioned, and the teaching technology is backward. We are still teaching with boring textbooks, which cannot be integrated into multimedia. Ignoring the practical training of students' ideological and political education, only blindly instilling theoretical knowledge, resulting in the disenchantment of students and their low enthusiasm for the study of ideological and political lessons, which makes the effect of education on ideological and political lessons not very obvious. 
At present, with the continuous advancement of socialist construction, the state and the party have put forward higher requirements on the ideological and political level of college students. Therefore, it is necessary for us to improve the construction of teachers, strengthen students' ideological and political education, and integrate new media into education of ideological and political work, so as to better meet the needs of the country[2].

\section{Problems Existing in Ideological and Political Work in Colleges and Universities}

\subsection{Backward teaching methods}

Our country's ideological and political education work has a long history, but the teaching methods, ideas and means are still in the last century. In the education of the ideological and political lesson, the teacher's teaching idea is only taught through the textbook, while the student passively receives the knowledge to carry on the study, this makes the student's learning initiative and the subjectivity are low, the classroom teaching effect is relatively poor. In addition, teachers still use textbooks for education teaching, and cannot use the latest media for teaching. These are all problems we need to pay attention to.

\subsection{Backward construction of ideological and political teachers}

The entry threshold for the teachers of the ideological and political course is relatively low, mainly because the ideological and political course, as a public course, is not highly valued. In order to meet the teaching tasks of ideological and political lessons, colleges and universities have low standards in selecting teachers of ideological and political lessons, which leads to the low level of teaching and ideological and political levels of some teachers. The teacher's level is relatively low, which is reflected in the students' general ideological and political level, without sufficient political literacy. Therefore, the construction of ideological and political teachers is also a problem that cannot be ignored in the development of ideological and political work.

\subsection{Can't face the age of omni media correctly}

In the age of omni media, information spreads very fast, and some bad ideas in the Internet bring great challenges to the development of ideological and political work. But the development of new media technology also brings us new opportunities. The ideological and political teacher should not regard the Omni-Media era as the enemy of ideological and political work. However, now many teachers cannot conform to the trend of The Times, but simply refuse the use of new media, and it is extremely unwise to try to go against the trend of The Times through traditional teaching methods. Therefore, developing our ideology and politics in the omni media era is an important topic for us.

\section{Adjust the Means and Strategy of Ideological and Political Work in Colleges and Universities under The Omni-Media Era}

In the age of Omni-Media, people will receive a large amount of information, and it is extremely difficult to distinguish the true and false information, which makes it more difficult to carry out ideological and political work in universities. It is unrealistic to try to improve students' ideological and political level by only relying on the education of ideological and political teachers. Therefore, it is necessary to teach students the ability to discriminate information and improve their judgment, so as to not accept false information. This can greatly improve students' ideological and political level. Therefore, the ideological and political work in our universities should be carried out in a certain strategic adjustment, so as to conform to the trend of The Times and complete the requirements of ideological and political work.

\subsection{Improve our understanding of the Omni-Media era and the media literacy of teachers and students}

We should introduce more technological means of the Omni-Media era into the classroom, strengthen the cultivation of the media quality of students and teachers, so that teachers and students can be exposed to new media means, strengthen literacy, and improve the ability to identify information[3]. In all the media age, improve the students' media literacy is of great significance for the development of ideological 
and political work, universities should set up related courses in the school, let the students to realize fully the characteristics of the media era, and realize that the shortage of the new media, cannot blindly trust the spread of the Internet information, for the information on the net have their own identification, not weak nor published detrimental to national security, social stability, consciously abide by the relevant laws and regulations, it has to keep students away from bad ideas. Of course, this also to our teacher's media literacy put forward higher request, the teacher should actively take the initiative to contact means of new media, so to understand the social events and public opinion direction, before bad thoughts influence students, for students to guide, let the students to look at things objectively, which have great benefits for the development of ideological and political work.

\subsection{Reduce students' dependence on the Internet}

Although the omni-media era has come, Internet technology and various multimedia means have been deep into people's lives. But students should reduce their dependence on the Internet. Due to the rapid development of smart phones, students of colleges and universities for smart phones use frequency is very high, some students have mobile phone addiction, even to eat sleeping with his or her mobile phone in the toilet, it caused them to network information too much contact, it is easy to accept by some bad ideas, which resulted in the reduction of ideological and political level, and on the other hand, will also bring tremendous to student's normal life, so it is necessary to call for students to reduce the use of mobile phones, to reduce dependence on the Internet.

\subsection{Improve students' ability to discriminate information}

In the age of Omni-Media, information explosion, students will have too much access to some information, which requires students to be able to effectively identify false information and reactionary speech in the process of contact. Therefore, it is necessary for us to guide students to examine various media means, answer students' questions in contact with information in a timely manner, and hold regular lectures for students, so as to fundamentally improve their ideological and political literacy. In the online life, students also need to actively guide the public opinion. For some reactionary remarks and remarks harmful to the society, they should actively report, keep the Internet environment clean and create a good Internet environment for the students in other universities, which is of great significance to the harmony and stability of the whole society.

\subsection{Strengthen supervision of media}

In the age of omni media, various media means are very rapid in the dissemination of information, and the authenticity is difficult to be guaranteed. Therefore, it is necessary to strengthen supervision. For some false information, it should be handled in a timely manner and not be guided by bad thoughts and speeches. The rapid development of information technology has led to the spread of information in the online life. Anyone can express his or her views in the online life. We must strengthen regulation and punish organizations and individuals for making false statements, and not make cyberspace a legal place.

\section{Conclusion}

In the age of Omni-Media, information dissemination is very rapid. This has brought great challenge to our university's ideological and political work. But it is also a new opportunity. We should take the initiative to learn some basic features of Omni-Media. Only in this way can we follow the trend of The Times, improve our methods of ideological and political work, and then solve some problems in the current ideological and political work in colleges and universities. The research topic of this paper is beneficial to effectively improve students' ideological and political literacy and create a good campus atmosphere.

\section{Acknowledgment}

This paper is one of the achievements of Research on General Secretary Xi Jinping's Thought about Youth Talents in the New Era (No.: I 2018002), a 2018 approved project of Wuhan Technology and Business University hosted by Xiao Juan. 


\section{Reference}

[1] Luo Xin. What is "Omni-Media" [J].Chinese journalist.2010 (03)

[2] Zhao Yong. Research teaching of ideological and political theory course: a case study of "Mao Zedong thought and introduction to the theoretical system of socialism with Chinese characteristics"[J]. Ideological \& Theoretical Education. 2009(09).

[3] Yang Wei. A multidimensional perspective on the development situation of contemporary ideological politics education [J]. Ideological \& Theoretical Education. 2009(09). 